\title{
Pengaruh Campuran NPK Phonska dan Pupuk Organik Cair Hantu Terhadap Produksi Pakcoy Sistem Hidroponik Media Padat
}

\author{
Lilian Safitri ${ }^{* *}$ dan Hendri Yandri ${ }^{2}$ \\ 1,2 Widyaiswara Balai Pelatihan Pertanian Jambi, Jl. Jambi Palembang KM 16 \\ Desa Pondok Meja Kecamatan Mestong, Kabupaten Muaro Jambi \\ Provinsi Jambi \\ 1 Email: liliansafitri2019@gmail.com \\ *Penulis korespondensi: liliansafitri2019@gmail.com
}

Revisi: 11-6-2021

Diterima: 17-6-2021

\begin{abstract}
The hydroponic system has been widely used by the community, especially in narrow land such as in the yard. But lately people have making experiment of nutrient because of the high cost of hydropnic fertilizer. This study aims to determine the correct dosage of NPK fertilizer in increasing pakcoy production by using solid media (cocopeat and sand) and it can replace $A B$ Mix fertilizer. The research was carried out at the Screen House of the Jambi Agricultural Training Center for 3 months (from November 2019) using a completely randomized design where there were 4 treatments, namely $A$ (AB Nutrient Mix as control), $B$ (1 kg NPK Phonska/200 L water $+2 \mathrm{~mL} \mathrm{L^{-1 }}$ of Hantu liquid organic fertilizer), $C$ (1.5 kg NPK Phonska/200 L water $+2 \mathrm{~mL} \mathrm{~L}^{-1}$ of Hantu liquid organic fertilizer), and D (2 kg NPK Phonska/200 L water $+2 \mathrm{~mL} \mathrm{L^{-1 }}$ of Hantu liquid organic fertilizer). The experiment was repeated 6 times in order to obtain 24 experimental units with high nutrition in an environment of $5 \mathrm{~cm}$ and $10 \mathrm{~cm}$ from the surface of the experimental pot, so that the total number of treatments became $2 \times 24=48$ experimental units. The part of the plant that was observed was plant height and production. The results showed that the total production of pakcoy which was given treatment $B$ was higher, reaching $317.67 \mathrm{~g} \mathrm{pot}^{-1}$ (5 cm inundation height) and $184 \mathrm{~g} \mathrm{pot}^{1}(10 \mathrm{~cm}$ inundation height).
\end{abstract}

Keywords: Hantu Liquid Organic Fertilizer, NPK Phonska, Pakcoy, Production, Solid Media Hydroponic System

\begin{abstract}
ABSTRAK
Sistem hidroponik sudah banyak dimanfaatkan masyarakat terutama di lahan sempit seperti di pekarangan rumah. Akhir-akhir ini masyarakat mencoba membuat nutrisi sendiri karena mahalnya pupuk khusus hidroponik. Penelitian ini bertujuan untuk mengetahui campuran NPK Phonska dan Pupuk Organik Cair (POC) Hantu dalam bentuk larutan yang tepat untuk meningkatkan produksi pakcoy dengan sistem hidroponik menggunakn media padat berupa campuran cocopeat dan pasir. Penelitian telah dilaksanakan di Screen House Balai Pelatihan Pertanian Jambi selama 3 bulan (dari bulan November 2019). Metode penelitian menggunakan Rancangan Acak Lengkap dengan 4 perlakuan yaitu $A$ ( $A B$ Mix nutrisi sebagai kontrol), B (1 kg NPK Phonska/200 L air $+2 \mathrm{~mL} \mathrm{~L}^{-1}$ POC Hantu), C (1,5 kg NPK Phonska/200 L air $+2 \mathrm{~mL} \mathrm{~L}^{-1}$ POC Hantu), dan D (2 kg NPK Phonska/200 L air + 2 $\mathrm{mL} \mathrm{L}^{-1} \mathrm{POC}$ Hantu) dengan tinggi genangan nutrisi pada saat diaplikasikan yaitu 5 $\mathrm{cm}$ dan $10 \mathrm{~cm}$. Penelitian ini diulang sebanyak 6 kali sehingga diperoleh 24 satuan penelitian dengan jumlah seluruhnya adalah 48 satuan penelitian. Bagian dari
\end{abstract}


tanaman yang diamati adalah tinggi tanaman dan produksi. Hasil akhir menunjukkan total produksi pakcoy yang diberi perlakuan B lebih tinggi yaitu mencapai 317,67 $\mathrm{g} \mathrm{pot}^{-1}$ (tinggi genangan $5 \mathrm{~cm}$ ) dan $184 \mathrm{~g} \mathrm{pot}^{-1}$ (tinggi genangan $10 \mathrm{~cm}$ ).

Kata kunci: NPK Phonska, Pakcoy, Produksi, Pupuk Organik Cair Hantu, Sistem Hidroponik Media Padat

\section{Pendahuluan}

Akhir-akhir ini sistem pertanian hidroponik cukup diminati sebagian petani yaitu melakukan budidaya pertanian tanpa menggunakan media tanah dan hanya menggunakan air. Menurut Triutami (2021) ada beberapa keunggulan hidroponik, diantaranya: mudah dipanen, hasil produksi jauh lebih tinggi, menggunakan media padat bukan tanah, nutrisi dan air lebih tersedia, serta mudah dalam pengendalian serangan hama dan penyakit tanaman. Namun, sistem hidroponik juga mempunyai kekurangan, yaitu: tidak ada penyangga sehingga hanya tanaman berumur pendek yang dapat dibudidayakan, kegagalan pada saat pembibitan mengakibatkan kerugian terutama saat dipaksakan untuk dipindahkan langsung ke media tanam. Kelemahan lainnya termasuk serangan patogen seperti karena layu misalnya oleh Verticillium akibat tingkat kelembaban tinggi dan penyiraman yang lebih ke tanaman. Selain itu, budidaya pada sistem hidroponik membutuhkan nutrisi yang berbeda sesuai dengan varietas tanaman yang ditanam.

Dalam hal ini, ada beberapa solusi yang sudah mulai diterapkan dalam menggunakan sistem hidroponik, salah satunya mengganti sistem instalasi yang relatif mahal dengan menggunakan media tanam padat yang dapat menyimpan air lebih banyak. Ada beberapa media padat yang dapat dimanfaatkan, diantaranya: cocopeat, ijuk, peat moss, kerikil, dan pasir. Selain memiliki pori-pori yang besar dan mampu menyimpan air lebih banyak, media tanam ini juga sangat mudah didapatkan di lingkungan sekitar. Selain itu, media ini juga dapat menahan akar tanaman agar dapat tumbuh dengan baik terutama tanaman dengan perakaran pendek dan dangkal, seperti sayur-sayuran misalnya pakcoy (family sawi).

Menurut Fahrudin (2009) pakcoy banyak mengandung vitamin dan mineral yang dibutuhkan oleh tubuh baik dalam bentuk kalori, protein, karbohidrat, serat, vitamin $A, B$, dan C. Akhir-akhir ini luasan lahan untuk tanaman pakcoy di Provinsi Jambi mengalami penurunan, terutama di Kota Jambi. Dari data Badan Pusat Statistik (2017) luasan lahan untuk tanaman pakcoy di Kota Jambi mencapai 173 ha. Namun, luasan ini berkurang pada tahun 2018 menjadi 143.62 ha. Selain terjadinya penyempitan lahan, juga belum tepatnya teknik budidaya yang diterapkan oleh petani (ditemukan daun berwarna kuning), 
serta sarana dan prasarana pertanian yang kurang memadai. Selain itu juga seringnya serangan ulat daun sehingga pakcoy tidak layak jual.

Penelitian ini bertujuan untuk mendapatkan komposisi nutrisi murah yang mudah dibuat oleh petani sebagai pengganti nutrisi hidroponik yang harganya mahal. Selain itu, penelitian ini bertujuan untuk menunjang penelitian selanjutnya berupa teknologi hidroponik sederhana dan murah sebagai mesin tanam sederhana dengan pemeliharaan yang mudah, sehingga dapat menjadi sumber pendapatan sampingan yang bernilai ekonomi relatif tinggi.

\section{Metodologi Penelitian}

Penelitian ini telah dilaksanakan di Screen House Balai Pelatihan Pertanian Jambi selama 3 bulan (dari bulan November 2019). Metode dalam penelitian ini menggunakan metode komparatif dengan membandingkan Kontrol (pupuk $A B$ Mix) dengan nutrisi pengganti berupa campuran NPK Ponska pada berbagai konsentrasi, kemudian juga ditambahkan POC Hantu (sebagai sumber unsur mikro). Penelitian ini menggunakan Rancangan Acak Lengkap dengan 4 perlakuan yaitu Perlakuan A (AB Mix sebagai kontrol yang diberikan sesuai takaran yang tertera pada kemasan), Perlakuan B (1 kg NPK Phonska/200 L air + 2 mL L-1 POC Hantu), Perlakuan C (1,5 kg NPK Phonska/200 L air + $2 \mathrm{~mL} \mathrm{~L}^{-1}$ POC Hantu), dan Perlakuan D (2 kg NPK Phonska/200 L air + $2 \mathrm{~mL} \mathrm{~L}^{-1}$ POC Hantu). Setiap perlakukan diulang sebanyak 6 kali sehingga diperoleh 24 satuan penelitian. Penelitian ini menggunakan sistem hidroponik dengan media padat berupa cocopeat yang dicampur dengan pasir (1:1) dan dimasukkan ke dalam pot percobaan (ember) dengan kapasitas 10 liter. Masing-masing pot penelitian tersebut diberi lubang setinggi 5 dan $10 \mathrm{~cm}$ dari dasar pot secara melingkar.

Untuk penyiapan bibit tanaman, benih pakcoy dibibitkan di dalam rockwool dan dibiarkan selama 1 minggu, kemudian dipindahkan ke media tanam dan diberi perlakuan. Dalam pemeliharaannya, ada beberapa kegiatan yang dilakukan yaitu diberikan pengendalian hama tanaman pakcoy terutama serangan ulat daun. Kemudian untuk menjaga ketersediaan nutrisi didalam media, juga ditambahkan nutrisi sesuai dengan perlakuan dimana untuk tinggi genangan $5 \mathrm{~cm}$ diberikan 2 hari sekali, sedangkan untuk tinggi genangan $10 \mathrm{~cm}$ diberikan dengan durasi 3 hari sekali. Adapun bagian tanaman yang diamati adalah tinggi tanaman yang diukur setelah tanaman berumur 7 hari setelah tanam (HST), 14 HST, 21 HST, dan 28 HST, serta produksi pakcoy yang ditimbang pada saat tanaman berumur 35 HST. Data tinggi tanaman dianalisis secara statistik dengan menggunakan Uji Anova taraf 5\% dan dilanjutkan dengan Uji Duncan's Multiple Range Test (DMRT) taraf 5\%. 


\section{Hasil dan Pembahasan}

\section{Pengaruh Campuran NPK Phonska dan Pupuk Organik Cair Hantu Terhadap Tinggi Tanaman Pakcoy}

Pakcoy merupakan tanaman sayuran yang berasal dari Asia Timur. Tanaman ini dapat tumbuh baik di dataran rendah maupun dataran tinggi dengan cahaya matahari yang cukup dan aerasi yang baik. Pertumbuhan pakcoy sangat didukung oleh kandungan hara baik unsur makro maupun unsur mikro terutama unsur nitrogen $(\mathrm{N})$. Kandungan $\mathrm{N}$ yang tinggi pada tanam pakcoy akan memudahkan proses pembentukan asam nukleat, dan mempercepat proses pembentukan klorofil di dalam jaringan daun. Menurut Margiyanto (2007) pakcoy tahan terhadap air hujan sehingga dalam budidayanya, diperlukan perhatian khusus terutama dalam penyiraman tanaman sampai produksi.

Dalam mendukung pertumbuhan vegetatif tanaman pakcoy maka dibutuhkan pupuk dalam jumlah yang cukup terutama yang mengandung unsur hara makro seperti unsur Nitrogen (N), Fosfor (P), dan Kalium (K). Menurut Aminifard et al., (2010) bahwa ketersediaan unsur $\mathrm{N}, \mathrm{P}$, dan $\mathrm{K}$ mampu mendorong dan meningkatkan produksi tanaman. Subandi et al., (2015) mengatakan setiap tanaman membutuhkan jenis dan jumlah hara yang berbeda untuk pertumbuhan dan peningkatan produksi tanaman. Tabel 1 merupakan data pengaruh campuran NPK Phonska dan POC Hantu dalam bentuk larutan yang diberikan dengan ketinggian $5 \mathrm{~cm}$ terhadap tinggi pakcoy.

Tabel 1. Pengaruh campuran NPK Phonska dan POC Hantu dalam bentuk larutan setinggi $5 \mathrm{~cm}$ terhadap tinggi pakcoy

\begin{tabular}{ccccc}
\hline \multirow{2}{*}{ Perlakuan } & \multicolumn{4}{c}{ Pengamatan Ke- (cm) } \\
\cline { 2 - 5 } & $\mathbf{7 ~ H S T}$ & $\mathbf{1 4}$ HST & 21 HST & 28 HST \\
\hline A & $19,0^{\mathrm{a}}$ & $21,2^{\mathrm{a}}$ & $25,2^{\mathrm{a}}$ & $27,2^{\mathrm{a}}$ \\
B & $13,5^{\mathrm{b}}$ & $14,5^{\mathrm{b}}$ & $15,4^{\mathrm{b}}$ & $17,5^{\mathrm{b}}$ \\
C & $15,6^{\mathrm{b}}$ & $15,7^{\mathrm{b}}$ & $16,0^{\mathrm{b}}$ & $16,8^{\mathrm{b}}$ \\
D & $10,6^{\mathrm{b}}$ & $11,4^{\mathrm{b}}$ & $12,6^{\mathrm{b}}$ & $13,5^{\mathrm{b}}$ \\
\hline
\end{tabular}

Keterangan: Angka-angka yang diikuti oleh huruf kecil yang sama berbeda tidak nyata menurut DMRT taraf 5\%; HST: Hari Setelah Tanam

Tabel 1 menunjukkan belum adanya pengaruh perlakuan dengan ketinggian genangan $5 \mathrm{~cm}$ terhadap tinggi tanaman pakcoy. Pengamatan yang telah dilakukan pada 7, 14, 21, 28 HST menunjukkan bahwa penggunaan AB Mix meningkatkan tinggi tanaman hingga $27,2 \mathrm{~cm}$ jika dibandingkan dengan perlakuan menggunakan campuran NPK Phonska dan POC Hantu dalam bentuk larutan. Pada pengamatan Minggu I setelah tanam, tinggi tanaman dengan menggunakan pupuk $A B$ Mix mencapai 19,0 cm, hal ini berbeda dengan perlakuan $B, C$, dan $D$ yaitu hanya $10,6 \mathrm{~cm} ; 13,5 \mathrm{~cm}$; dan $15,6 \mathrm{~cm}$, begitu juga pada pengamatan ke II, III, dan IV dimana AB Mix lebih berdampak terhadap tinggi tanaman pakcoy yang ditanam pada sistem hidroponik media padat (campuran cocopeat dan pasir). Pupuk AB Mix mengandung berbagai jenis unsur hara esensial yang 
dibutuhkan oleh tanaman, seperti N, P, K, Ca, Mg, S serta beberapa unsur mikro serta lebih cepat tersedia pada sistem hidroponik. Hasil penelitian yang sama juga diinformasikan oleh Purwanto et al., (2019) bahwa nutrisi AB mix mampu meningkatkan hasil sayuran family sawi.

Tingginya tanaman pakcoy dengan penambahan AB Mix juga disebabkan karena tingginya kandungan $\mathrm{N}$ yang tersedia didalam pupuk tersebut, baik dalam bentuk $\mathrm{NH}_{4}{ }^{+}$ maupun $\mathrm{NO}_{3}$. Menurut Lingga (2001) nitrogen merupakan salah satu unsur yang dapat merangsang pertumbuhan tanaman secara keseluruhan, terutama pada akar, batang, dan daun. Nitrogen merupakan unsur hara yang sangat dibutuhkan dalam jaringan tanaman karena merupakan penyusun asam amino, protein, dan enzim. Selain itu juga terkandung dalam klorofil, hormon sitokinin, dan auksin (Lakitan, 2008).

Tabel 1 juga menunjukkan jika dibandingkan antara perlakuan $B, C$, dan D maka perlakuan $\mathrm{C}$ lebih memperlihatkan dampak terhadap tinggi tanaman pakcoy selama 3 minggu pengamatan. Namun pertumbuhan tanaman mengalami penurunan sehingga mempengaruhi tinggi tanaman pada minggu ke 4 (28 HST). Hasil lapangan menunjukkan adanya serangan hama ulat daun sehingga sebagian daun mengalami layu. Menurut Kardinan (2000) hama ulat pakcoy umumnya memakan daun dengan membuat lubanglubang baik pada daun muda maupun daun tua. Hardyati et al., (2019) serangan ulat daun pada tanaman sawi termasuk pakcoy dapat menurunkan kualitas dari tanaman itu sendiri.

Tabel 2 menunjukan perlakuan campuran pupuk NPK Phonska dan POC Hantu yang telah dilarutkan pada pot penelitian dengan ketinggian genangan $10 \mathrm{~cm}$ juga tidak memperlihatkan pengaruh terhadap tinggi tanaman pakcoy. Perlakuan $\mathrm{A}$ (kontrol) masih menunjukkan pengaruh yang nyata terhadap tinggi tanaman. Pada pengamatan ke-I (7 HST) tinggi pakcoy mencapai $18,20 \mathrm{~cm}$ jika dibandingkan dengan perlakuan campuran NPK Phonska dan POC Hantu dimana tertinggi hanya $12,10 \mathrm{~cm}$ (perlakuan B10), begitu juga pertambahan tinggi tanaman pakcoy pada pengamatan ke-II, III, dan IV.

Tabel 2. Pengaruh campuran NPK Phonska dan POC Hantu dalam bentuk larutan setinggi $10 \mathrm{~cm}$ terhadap tinggi pakcoy

\begin{tabular}{ccccc}
\hline \multirow{2}{*}{ Perlakuan } & \multicolumn{4}{c}{ Pengamatan Ke- (cm) } \\
\cline { 2 - 5 } & $\mathbf{7 ~ H S T}$ & $\mathbf{1 4 ~ H S T}$ & $\mathbf{2 1 ~ H S T}$ & 28 HST \\
\hline A & $18,2^{\mathrm{a}}$ & $25,0^{\mathrm{a}}$ & $26,2^{\mathrm{a}}$ & $27,0^{\mathrm{a}}$ \\
B & $12,1^{\mathrm{b}}$ & $13,0^{\mathrm{b}}$ & $14,0^{\mathrm{b}}$ & $14,5^{\mathrm{b}}$ \\
C & $11,5^{\mathrm{b}}$ & $12,5^{\mathrm{b}}$ & $13,6^{\mathrm{b}}$ & $15,5^{\mathrm{b}}$ \\
D & $10,0^{\mathrm{b}}$ & $11,4^{\mathrm{b}}$ & $11,4^{\mathrm{b}}$ & $13,0^{\mathrm{b}}$
\end{tabular}

Keterangan: Angka-angka yang diikuti oleh huruf kecil yang sama berbeda tidak nyata menurut DMRT taraf 5\%; HST: Hari Setelah Tanam

Campuran NPK Phonska dan POC Hantu pada Tabel 2 menujukkan rendahnya pengruh terhadap tinggi tanaman. Hal ini disebabkan karena adanya faktor durasi 
penambahan perlakuan selama pemeliharaan yaitu per 3 hari sekali yang mengakibatkan nutrisi tidak cukup pada hari ke 3 yang ditandai dengan keringnya permukaan media tanam (campuran cocopeat dan pasir). Menurut Hasriani et al., (2013) cocopeat mempunyai daya simpan air yang tinggi dengan bobot isi yang ringan. Dalam hal ini, sangat mendukung ketersediaan pupuk didalam media tanam, sehingga sangat membantu pertumbuhan vegetatif tanaman. Namun, pasir yang dicampurkan dengan cocopeat mengakibatkan pori-pori lebih longgar pada media tanam. Dengan demikian, screen house dengan suhu lebih tinggi mengakibatkan nutrisi lebih cepat kering. Novizan (2019) berpendapat pertumbuhan dan produksi tanaman sangat dipengaruhi oleh jenis nutrisi yang diberikan mulai dari penanaman hingga panen. Salah satunya adalah upaya dalam menjaga frekuensi pemberian nutrisi ke media tanam.

Dari Tabel 1 dan 2 terlihat bahwa penggunaan pupuk NPK Phonska dapat meningkatkan tinggi tanaman pakcoy. Hal ini terlihat dari terjadinya penambahan tinggi tanaman pada pengamatan 2, 3, dan 4. Dimana pada perlakuan B (tinggi genangan $5 \mathrm{~cm}$ ) dan $C$ (tinggi genangan $10 \mathrm{~cm}$ ) lebih tinggi pada pengamatan terakhir, yaitu $17.5 \mathrm{~cm}$ dan $15,5 \mathrm{~cm}$. Jumlah pupuk yang diberikan pada perlakuan B (tinggi genangan $5 \mathrm{~cm}$ ) adalah 1 $\mathrm{kg} / 200 \mathrm{~L}$ air $+2 \mathrm{~mL} \mathrm{~L}{ }^{-1}$ POC Hantu, sedangkan pada Perlakuan C (tinggi genangan 10 $\mathrm{cm}$ ) jumlah pupuk yang diberikan adalah $1.5 \mathrm{~kg} / 200 \mathrm{~L}$ air $+2 \mathrm{~mL} \mathrm{~L}^{-1}$ POC Hantu. Pada saat tanaman pakcoy kekurangan unsur nitrogen maka tanaman akan tumbuh kerdil dan daun lebih cepat berubah menjadi kuning serta mudah terserang hama seperti ulat.

Selain itu, peranan POC Hantu dapat membantu menambah tinggi tanaman pakcoy. POC Hantu dikenal sebagai zat pengatur tumbuh (ZPT). Menurut Napitupulu et al., (2018) ZPt disebut sebagai hormon organik yang berperan dalam menunjang pertumbuhan tanaman, memperbesar sel, serta mempengaruhi pertumbuhan akar dan batang tanmaan. Nurahmi et al., (2010) mengatakan ZPT juga berperan dalam membantu kinerja hormon lain seperti auksin sehingga mamacu pertumbuhan tanaman.

\section{Pengaruh Campuran NPK Phonska dan POC Hantu Terhadap Produksi Pakcoy}

Berdasarkan hasil penelitian dan analisis sidik ragam menunjukkan penambahan campuran NPK Phonska dan POC Hantu dalam bentuk larutan dapat meningkatkan produksi pakcoy yang ditanam dengan menggunakan sistem hidroponik media padat (cocopeat dicampur pasir). Jumlah produksi pakcoy pada perlakuan B (tinggi genangan 5 $\mathrm{cm}$ ) lebih tinggi yaitu seberat 317,67 g dibandingkan kontrol yaitu 225,6 g. Gambar 1 menunjukkan pada pot penelitian C (tinggi genangan $5 \mathrm{~cm})(1,5 \mathrm{~kg}$ NPK Phonska/200 L air $+2 \mathrm{~mL} \mathrm{~L}^{-1}$ POC Hantu) dan D (tinggi genangan $\left.5 \mathrm{~cm}\right)(2 \mathrm{~kg} \mathrm{NPK}$ Phonska/200 L air +2 $\mathrm{mL} \mathrm{L} \mathrm{L}^{-1}$ POC Hantu), pengaruh campuran pupuk NPK Phonska dan POC Hantu dalam bentuk larutan belum mampu meningkatkan produksi pakcoy dibandingkan kontrol Jpt. Jurnal Pertanian Terpadu, Jilid 9, Nomor 1 | 100 
dimana selisih hasil produksinya mencapai 60,92-205,62 g. Hal ini disebabkan karena dosis pemupukan yang belum tepat untuk peningkatan produksi pakcoy secara maksimal sehingga diperlukan penelitian lanjutan. Selain itu, pada pengamatan Minggu ke-III juga ditemukan serangan hama berupa ulat daun yang merusak bagian daun pakcoy yang mengakibatkan daun tidak tumbuh optimal (layu dan membusuk di bagian pangkal daun) dan mati.

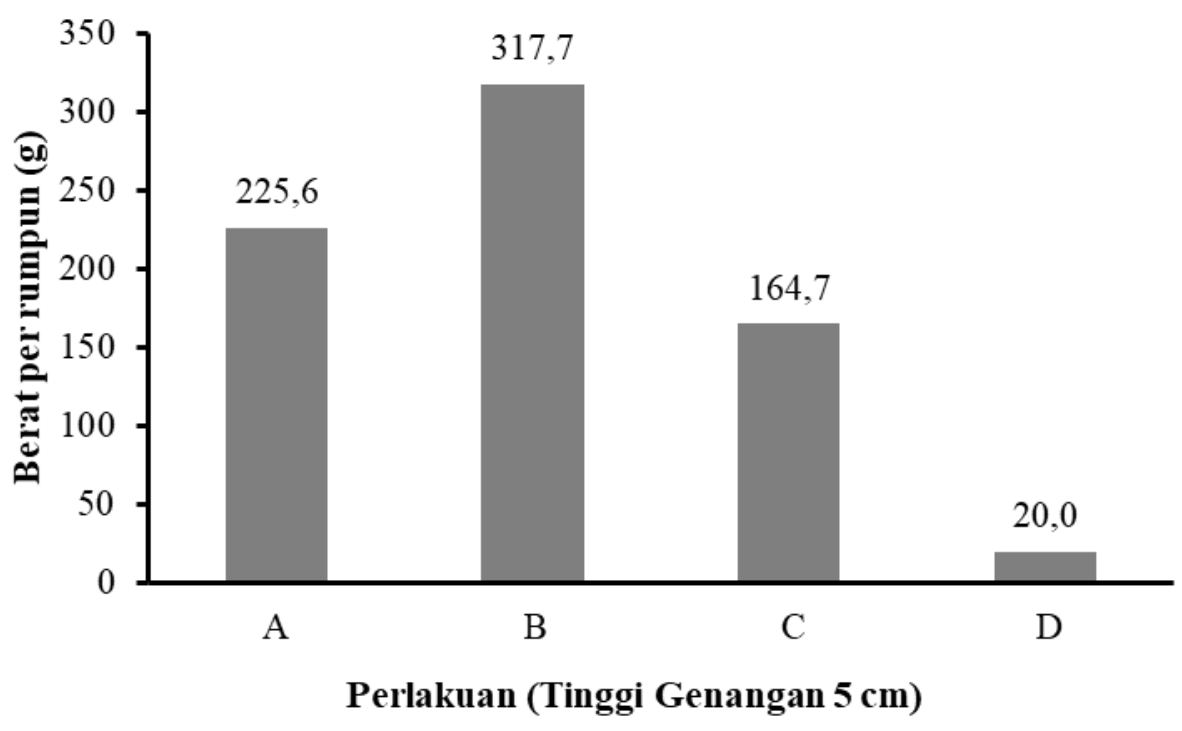

Gambar 1. Pengaruh campuran NPK Phonska dan POC Hantu dalam bentuk larutan dengan tinggi genangan $5 \mathrm{~cm}$ terhadap produksi pakcoy

Penambahan POC Hantu juga memberikan dampak terhadap berat produksi pakcoy sebagai zat hormon tumbuh. Hal ini disebabkan karena asam Giberelet yang terkandung dalam POC Hantu berpengaruh dalam pembelahan sel, perpanjangan sel, pembesaran sel, sehingga meningkatkan produksi (Lidar \& Mutryarny, 2017). Menurut Widodo et al., (2016) pemberian pupuk NPK Phonska dapat meningkatkan ketersediaan unsur hara $\mathrm{N}$ yang sangat dibutuhkan untuk pertumbuhan vegetatif tanaman. Tanaman dapat tumbuh dengan baik dan menghasilkan produksi yang tinggi diperlukan unsur hara atau makanan yang cukup. Unsur hara utama yang dibutuhkan oleh tanaman adalah unsur Nitrogen $(\mathrm{N})$ yang berperan menyusun protoplasma dan mempercepat pertumbuhan tanaman. Unsur fosfor $(P)$ berperan mempercepat serta memperkuat tanaman muda menjadi tanaman dewasa, selain itu juga dapat mempercepat pembesaran dan pemasakan buah, unsur Kalium (K) berperan membantu pembentukan protein dan karbohidrat dan unsur belerang (S) berperan membantu perkembangan tanaman.

Pada perlakuan B (genangan setinggi $10 \mathrm{~cm}$ ) menunjukkan adanya pengaruh pemupukan terhadap berat produksi jika dibandingkan kontrol, dimana berat produksi 
lebih tinggi yaitu seberat 184,00 g (1,51\%). Pupuk NPK Phonska mengandung unsur hara makro terutama $15 \% \mathrm{~N}, 15 \% \mathrm{P}_{2} \mathrm{O}_{5}$, dan $15 \% \mathrm{KCl}$. Hal ini tentunya berpengaruh terhadap kebutuhan nitrogen oleh tanaman terutama tanaman sayuran. Pada pupuk AB Mix, untuk kandungan nitrogen sebesar $9.90 \% \mathrm{NO}_{3}$ dan $0.48 \% \mathrm{NH}_{4}$ mampu memberikan pengaruh yang besar terhadap pertumbuhan vegetatif tanaman sayuran, disebabkan karena tersedia cukup cepat, selengkapnya disajikan pada Gambar 2.

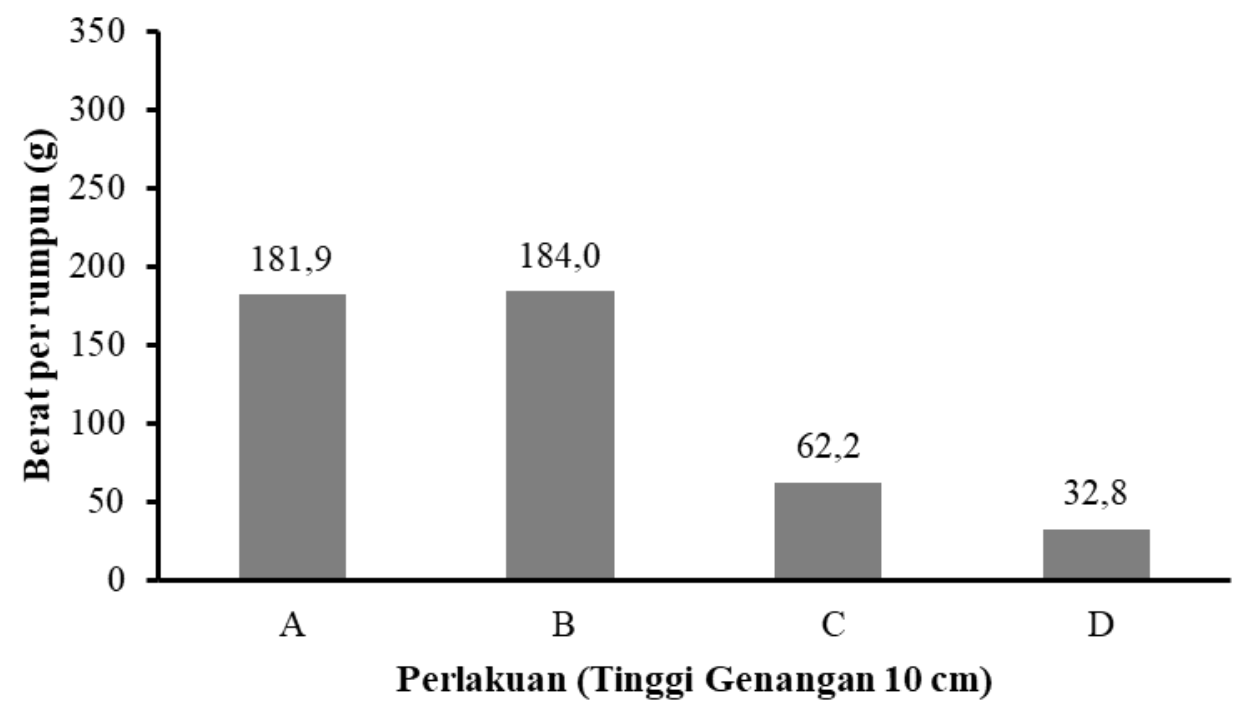

Gambar 2. Pengaruh campuran NPK Phonska dan POC Hantu dalam bentuk larutan dengan tinggi genangan $10 \mathrm{~cm}$ terhadap produksi pakcoy

Pada Gambar 2 terlihat perlakuan $C$ dan $D$ belum memberikan pengaruh terhadap produksi tanaman pakcoy, dimana hasil produksi hanya 32,75-62,17 g/pot penelitian. Hal ini berbeda signifikan dengan perlakuan $A$ menggunakan nutrisi $A B$ Mix dengan selisih 149,15-119,73 g pot- $^{-1}$. Menurut Sukawati (2010) berat segar total tanaman dipengaruhi proses fotosintesis dalam pembentukan organ dan jaringan tanaman yang berpengaruh terhadap berat daun (produksi tanaman). Subandi et al., (2015) mengatakan ketersediaan unsur $\mathrm{N}$ dan $\mathrm{Mg}$ juga mempengaruhi proses fotosintesis di dalam jaringan tanaman. Pada penelitian ini, unsur $\mathrm{N}$ diperoleh dari perlakuan yang diberikan. Prastowo et al., (2013) mengatakan dengan tersedianya unsur $\mathrm{N}$ maka tanaman akan mampu membentuk protoplasma dalam jumlah yang lebih banyak sehingga akan meningkatkan berat segar tanaman.

Menurut Mas'ud (2009) nutrisi dan media tanam yang berbeda maka akan memberikan hasil produksi yang berbeda. Dal hal ini dibutuhkan ketepatan dalam pemilihan media tanam dan konsentrasi nutrisi terutama pada system hidroponik. Senada juga disampaikan oleh Wasonowati et al., (2013) ketersediaan hara yang rendah akan menghambat pertumbuhan tanaman dan menurunkan produksi. Produksi vegetatif 
tanaman merupakan hasil dari metabolisme tanaman. Menurut Agustin (2018) berat segar tanaman dipengaruhi oleh kandungan nutrisi yang diserap oleh akar tanaman. Hasil penelitian ini menunjukkan bahwa jumlah nutrisi yang tepat dengan media tanam yang tepat dapat meningkatkan produksi pakcoy. Nabihaty (2011) mengatakan bahwa pemupukan yang efektif harus tepat kualitas dan kuantitasnya, yaitu tepat dosis, tepat jenis pupuk, tepat waktu pemberian serta unsur yang ditambahkan memang yang dibutuhkan oleh tanaman termasuk dalam sistem hidroponik yang menggunakan media non tanah.

\section{$4 \quad$ Kesimpulan}

Dari hasil penelitian, campuran NPK Phonska sebanyak $1 \mathrm{~kg} / 200 \mathrm{~L}$ air dengan 2 $\mathrm{mL} \mathrm{L}^{-1}$ air dalam bentuk larutan yang diberikan setinggi $5 \mathrm{~cm}$ pada ember kapasitas $10 \mathrm{~L}$ mempengaruhi tinggi tanaman dengan tinggi $17,5 \mathrm{~cm}$ dan berproduksi hingga $317,67 \mathrm{~g}$ rumpun $^{-1}$. Berdasarkan jumlah produksi, penggunaan campuran NPK Phonska dan POC Hantu dengan dosis yang tepat dapat menggantikan penggunaan nutrisi $A B$ mix yang diaplikasikan pada media padat.

\section{Daftar Pustaka}

Agustin, O. (2018). Pengaruh Media Tanam Secara Hidroponik Terhadap Pertumbuhan Bayam Merah (Amarathus tricolor L.). Skripsi. Program Studi Teknik Pertanian Jurusan Agroekoteknologi Fakultas Pertanian Universitas Sriwijaya.

Aminifard, M. H., Aroiee, H., Fatemi, H., Ameri, A., \& Karimpour, S. (2010). Responses of Eggplant (Solanum melongena L.) to Different Rates of Nitrogen Under Field Conditions. Journal of Central European Agriculture, 11(4), 453-458. https://doi.org/10.5513/jcea01/11.4.863

Badan Pusat Statistik. (2017). Produksi Sayuran dan Buah-buahan Provinsi Jambi. Salim Media Indonesia.

Fahrudin, F. (2009). Budidaya Caisim (Brassica junacea) Menggunakan Ekstrak Teh dan Pupuk Kascing. Skripsi. Universitas Sebelas Maret.

Hardyati, L., Hamyana, \& Pratiwi, A. (2019). Penggunaan Berbagai Macam Biopestisida Pada Tindakan Preventif dan Kuratif Terhadap Ulat Daun (Plutella xylostella) Pada Tanaman Sawi Pakcoy (Brassica rapa subsp chinensis). Jurnal Agriekstensia, 18(2), 103-110.

Hasriani, D., Kalsim, K., \& Sukendro, A. (2013). Kajian Serbuk Sabut Kelapa (cocopeat) Sebagai Media Tanam. Jurnal Horti, 16(3), 66-72.

Kardinan, A. (2000). Pestisida Nabati, Ramuan dan Aplikasi. Jakarta: Penebar Swadaya.

Lakitan, B. (2008). Dasar-Dasar Fisiologi Tumbuhan. Jakarta: Raja Grafindo Persada.

Lidar, S., \& Mutryarny, E. (2017). Uji ZPT Hantu Terhadap Pertumbuhan dan Produksi Selada Merah (Lactuca sativa). Jurnal Ilmiah Pertanian, 13(2), 89-96.

Lingga, P. M. (2001). Petunjuk Penggunaan Pupuk. Jakarta: Penebar Swadaya. 
Margiyanto, E. (2007). Hortikultura. Bantul: Cahaya Tani.

Mas'ud, H. (2009). Sistem Hidroponik dengan Nutrisi dan Media Tanam Berbeda Terhadap Pertumbuhan dan Hasil Selada. Media Litbang Sulteng, 2(2), 131-136.

Nabihaty, F. (2011). Koleksi Pupuk. Yogyakarta: Laboratorium Kimia dan Kesuburan Tanah, Jurusan Tanah, Fakultas Pertanian, Universitas Gadjah Mada.

Napitupulu, N. S., Lubis, R., \& Sipayung, E. P. (2018). Pertumbuhan dan Produksi Tanaman Pakcoy (Brassica rapa) Secara Hidroponik Dengan Variasi Konsentrasi Larutan Hara dan ZPT. Prosiding Forum Komunikasi Perguruan Tinggi Pertanian Indonesia, 232-239. Banda Aceh: Universitas Syiah Kuala Banda Aceh.

Novizan, L. B. (2019). Petunjuk Pemupukan yang Efektif. Jakarta: Agro Media Pustaka.

Nurahmi, E., HAR, H., \& Mulyani, S. (2010). Pertumbuhan dan Hasil Kubis Bunga Akibat Pemberian Pupuk Organik Cair Nasa dan Zat Pengatur Tumbuh Hormonik. Jurnal Agrista, 14(1), 1-7.

Prastowo, B., Patola, E., \& Sarwono. (2013). Pengaruh Cara Penanaman dan Dosis Pupuk Urea Terhadap Pertumbuhan dan Hasil Tanaman Selada Daun (Lactuca Sativa L.). Jurnal Inovasi Pertanian, 12(2), 41-52.

Purwanto, E., Sunaryo, Y., \& Widata, S. (2019). Pengaruh Kombinasi Pupuk AB MIX dan Pupuk Organik Cair (POC) Kotoran Kambing Terhadap Pertumbuhan dan Hasil Sawi (Brassica juncea L.,) Hidroponik. Jurnal IImiah Agroust, 2(2), 11-24.

Subandi, M., Salam, N. P., \& Frasetya, B. (2015). Pengaruh Berbagai Nilai EC (Electrical Conductivity) Terhadap Pertumbuhan dan Hasil Bayam (Amaranthus sp) Pada Hidroponik Sistem Rakit Apung (Floating Hydroponic System). Jurnal ISTEK, 9(2), 136-152.

Sukawati, I. (2010). Pengaruh Kepekatan Larutan Nutrisi Organik Terhadap Pertumbuhan dan Hasil Baby Kailan (Brassica oleraceae Var.alboglabra) Pada Komposisi Media Tanam Dengan Sistem Hidroponik Subtrat Sebagai Nutrisi Pada Perbesaran Bibit Adenium, Sp. Dengan Sistem Hidropon. Skripsi. Universitas Sebelas Maret.

Triutami, T. (2021). Keunggulan dan Kelemahan Hidroponik. Retrieved March 1, 2021, from https://tiaratriutami.wordpress.com/2011/05/24/pengenalan-bercocok-tanamsecara-hidroponik-pada-petani-untuk-meningkatkan-kualitas-dan-kuantitas- hasilpertanian

Wasonowati, C., Suryawati, S., \& Rahmawati, A. (2013). Respon Dua Varietas Tanaman Selada (Lactuca sativa L.) Terhadap Macam Nutrisi Pada Sistem Hidroponik. J. Agrivor, 6(1), 50-56.

Widodo, A., Sujalu, A. P., \& Syahfari, H. (2016). Pengaruh Jarak Tanam dan Pupuk NPK Phonska Terhadap Pertumbuhan dan Produksi Tanaman Jagung Manis (Zea mays saccharata Sturt) Varietas Sweet Boy. Agrifor, XV(1), 171-178. 